\title{
A Survey on Antibiotic Usage in Dairy Herds in Pennsylvania
}

\author{
A. A. Sawant, ${ }^{1}$ L. M. Sordillo, ${ }^{2}$ and B. M. Jayarao ${ }^{1}$ \\ ${ }^{1}$ Department of Veterinary Science, Pennsylvania State University, University Park 16802 \\ ${ }^{2}$ Department of Large Animal Clinical Sciences, Michigan State University, East Lansing 48824
}

\section{ABSTRACT}

A survey was conducted (July 2001 to June 2002) on antibiotic usage of 113 dairy herds from 13 counties in Pennsylvania. Fifty percent of dairy farms surveyed maintained antibiotic treatment records. Only $21 \%$ of dairy producers had written plans for treating sick animals. Thirty-two percent of dairy producers sought veterinarian advice before administering antibiotics and on most farms (93\%), antibiotics were administered by the owner/manager or designated herdsman. Twentyfour percent of the dairy producers said they always completed the course of antibiotic treatment. Any extralabel use of antibiotics was administered only on the guidelines of a veterinarian on majority of the farms. Comprehensive records from 33 dairy farms indicated that antibiotic usage was largest for calves with enteritis (36\%) followed by pneumonia in calves (25\%) and foot rot in cattle (16\%). Twenty-four antibiotics including beta-lactams, spectinomycin, florfenicol, and tetracyclines were used on these farms. Beta-lactam antibiotics were used mostly for dry cow therapy, clinical mastitis, and on some farms for pneumonia and metritis. On $18 \%$ of the dairy herds surveyed, ceftiofur was used in an extra-label manner to treat mastitis in lactating cattle. On $70 \%$ of farms, calves were fed medicated milk replacers containing oxytetracycline and neomycin. The results of this study suggest that antibiotics are used extensively on dairy herds for both therapeutic and prophylactic purposes. Beta-lactams and tetracyclines were the most widely used antibiotics. There is considerable variation in the management practices associated with antibiotic use on dairy farms. It is anticipated that the findings of this survey will permit developing new strategies for prudent use of antibiotics on dairy herds.

(Key words: antibiotic use, dairy herd)

\section{INTRODUCTION}

Antibiotics are used in livestock production as therapeutics, growth promoters, and prophylactics. The ther-

Received December 10, 2004.

Accepted April 7, 2005.

Corresponding author: Bhushan Jayarao; e-mail: bmj3@psu.edu. apeutic regimen is dictated by label instructions from the manufacturer or in accordance with extra-label instructions from a veterinarian. Antibiotics used as growth promoters are administered at low doses for extended periods. As prophylactics, antibiotics are used at low doses to prevent disease. Although the duration of antimicrobial use differs for growth promotion and prophylaxis, the dosage for both is typically less than $200 \mathrm{~g} / \mathrm{ton}$, and is considered subtherapeutic (IOM, 1989).

At subtherapeutic levels, antibiotics are helpful in: 1) improving growth, 2) reducing risk of disease, 3) improving digestion, 4) improving weight gain, and 5) decreasing time and amount of feed needed to reach slaughter weight (Crawford and Teske, 1983; Droumev, 1983; Frost, 1991). Almost 90\% of all antibiotics used in farm animals and poultry are administered at subtherapeutic concentrations [Council for Agricultural Science and Technology (CAST), 1981]. About 70\% of all antibiotics used in subtherapeutic concentrations in animal feeds are given for the purpose of disease prevention (prophylaxis), whereas 30\% are used for growth promotion (CAST, 1981; Hays, 1986; US International Trade Commission, 1987).

A study that examined the use of antibiotics on conventional dairy farms in Michigan, Minnesota, New York, and Wisconsin reported that use of newer antibiotics such as ceftiofur was a common practice (Zwald et al., 2004). The authors observed high use of dry cow therapy on these farms, and approximately half of farms fed medicated milk replacers to calves. Some of the farms reported using antibiotics that were prohibited for use in dairy cattle. Small dairy producers in Kenya were observed to produce milk with beta-lactam residues exceeding the established maximum residue levels (Shitandi and Sternesjo, 2004). Use of antibiotics in Sweden and Norway for mastitis treatment has been influenced by national policies and recommendations (Grave et al., 1999). In these countries, the preference for using beta-lactams (i.e., procaine, benzyl penicillin, and combinations with dihydrostreptomycin) was based on the withdrawal period. Dairy producers in Sweden use long-acting drug treatment for subclinical mastitis and dry cow therapy, whereas the same formulations are not accepted in Norway. These examples 
indicate that antibiotic usage varies from country to country, within a country, and between farms, depending on policies and desired results.

The extensive use of antibiotics has led bacteria to adapt defenses against antibiotics (Levy, 1992). Selective pressure is a general concept that refers to the many factors that create an environmental landscape that allows organisms with novel mutations or newly acquired characteristics to survive and proliferate (Baquero et al., 1998). The classic example of continuous selective pressure in the animal production industry is the use of antibiotics in feed at subtherapeutic concentrations (IOM, 1989).

Usage of antibiotics is known to leave residues in farm products (Levy et al., 1987; Corpet, 1996; Tenover and McGowan, 1996). Antibiotics can enter the aquatic and terrestrial ecosystems through the discharge of effluents from farms (Bates et al., 1994). When applied to the land, farm wastes containing bioactive veterinary drug residues and antimicrobial-resistant bacteria are susceptible to runoff into bodies of water and can create reservoirs in the environment for antibiotic resistant bacteria (Austin, 1985; Chee-Sanford et al., 2001). To understand the public health risks associated with antibiotic usage within the dairy industry, it is important to define the type and specific use of antimicrobial agents that are associated with on-farm management practices.

\section{MATERIALS AND METHODS}

\section{Dairy Herds}

A total of 248 dairy farms from 36 counties in Pennsylvania were solicited to participate in the antibiotic usage survey. The 248 dairy farms had participated in an earlier study on foodborne pathogens in bulk tank milk (Jayarao et al., 2002). The dairy herds that participated in that study were referred by 19 county extension educators, and 3 milk cooperatives. The same 248 herds were contacted again and 173 of the dairy producers indicated their interest in participating in an antibiotic usage survey. Dairy producers were selected for the study if they: 1) would allow reviewing of available farm records related to antibiotic usage, 2) were currently members of DHIA, and 3) granted permission to contact their veterinarian to verify antibiotic use. The 126 dairy producers that met the study criteria were requested to take part in the survey. A total of 113 dairy producers ( $\mathrm{n}=13$ counties) participated in the survey. The dairy herds were categorized based on their herd size of $<100$ lactating cows $(n=42$ herds, 3 to 4 herds/county), between 100 and 199 lactating cows ( $\mathrm{n}=$ 45 herds, 3 to 5 herds/county), and $>200$ lactating cows ( $n=26$ herds, 2 herds/county). Thirty-three of the 113 dairy herds maintained complete records on individual animal health and antibiotic usage. Records from these herds were analyzed to determine the type of antibiotics that were used and the purpose for which they were administered.

\section{Survey Questionnaire}

A survey instrument (questionnaire) on antibiotic usage was developed for collecting information on antibiotic usage. The questionnaire survey was administered by the author to the dairy producer or manager of each farm. The first part of the survey was administered to all 113 dairy producers. The second part of the survey was administered to the 33 dairy producers who had records on herd health and antibiotics use. The survey was conducted from July 2001 through June 2002.

\section{Data Analyses}

Answers to the questionnaire were transferred to Microsoft Excel and grouped by the type of response (e.g., "yes" or "no") obtained. The response for each question was subjected to 1-way ANOVA to determine if there was any significant difference in their response. A $P$ value of $<0.05$ was considered as a significant difference in the type of response for a given question. All statistical analyses were performed using JMP software version 4.0 (SAS Institute, Cary, NC).

\section{RESULTS AND DISCUSSION}

The use of antibiotics in animal agriculture has been controversial because of the potential transfer of antibiotic resistance from animals to humans. Such transfer could have severe public health implications as it might lead to treatment failures and human costs, including death and prolonged illness, associated with such failures (Kelly et al., 2004). The survey conducted in this study included questions that were helpful to gain insight regarding farm management practices associated with antibiotic usage. One important finding of this study was the observation that only $50 \%$ of the farms surveyed kept written or computerized records of antibiotic treatment that could be verified (Table 1). Of these farms, only 33 producers maintained complete records of antibiotic usage. Kaneene and Ahl's (1987) survey of dairy producers in Michigan indicated that insufficient record keeping and poor knowledge about drug withdrawal periods among producers were important factors leading to drug residues in milk.

There was a significant difference in the number of dairy producers who did (21\%) and did not (79\%) have written plans for treating sick animals. Thirty-two per- 
Table 1. Response to questionnaire survey on use of antibiotics on dairy herds.

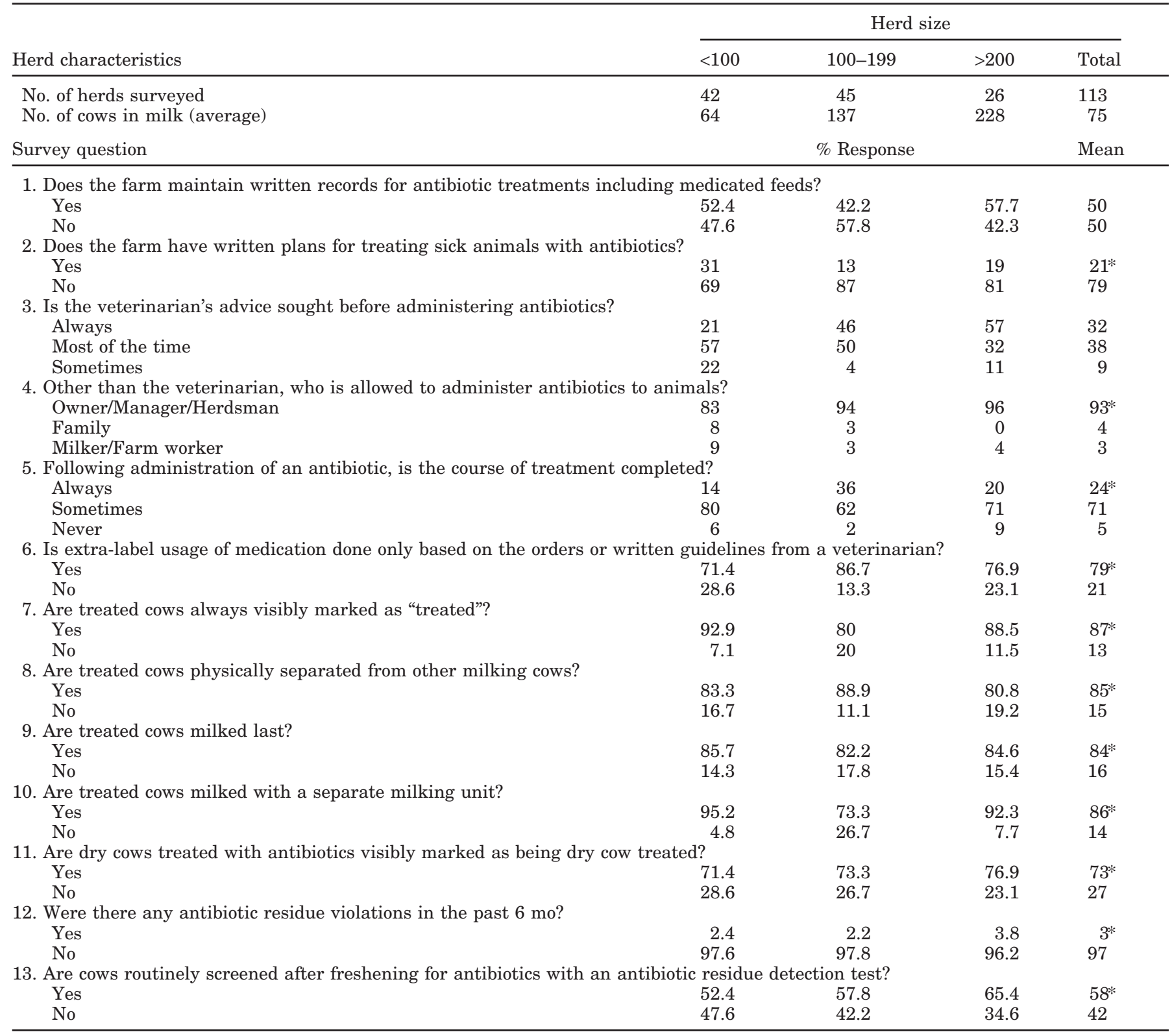

$* P<0.05$.

cent of farmers always sought veterinarian advice before administering antibiotics. Other than the veterinarian, antibiotics were administered primarily by the owner/manager or herdsman on $93 \%$ of farms. Only $24 \%$ of the dairy producers said that they always completed the course of antibiotic treatment presented for a given condition (Table 1). The tendency to rely on personal experience for antibiotic use, dosage, and withdrawal period was also observed in dairy producers surveyed by Zwald et al. (2004). This lapse could lead to improper antibiotic usage.
Another area where potential abuse of antibiotics occurs is extra-label use. The Animal Medicinal Drug Use Clarification Act of 1994 states that extra-label use must be by or on the order of a veterinarian and must not result in violative residues in food-producing animals (http://www.fda.gov/cvm/default.html, accessed Sept. 20, 2004). Administration of extra-label medication following the orders or written guidelines from a veterinarian was practiced on $79 \%$ of farms.

The use of antibiotics on farms always poses the risk of the milk becoming tainted with antibiotic residues. 
Table 2. List of antibiotics approved for use in dairy animals. ${ }^{1}$

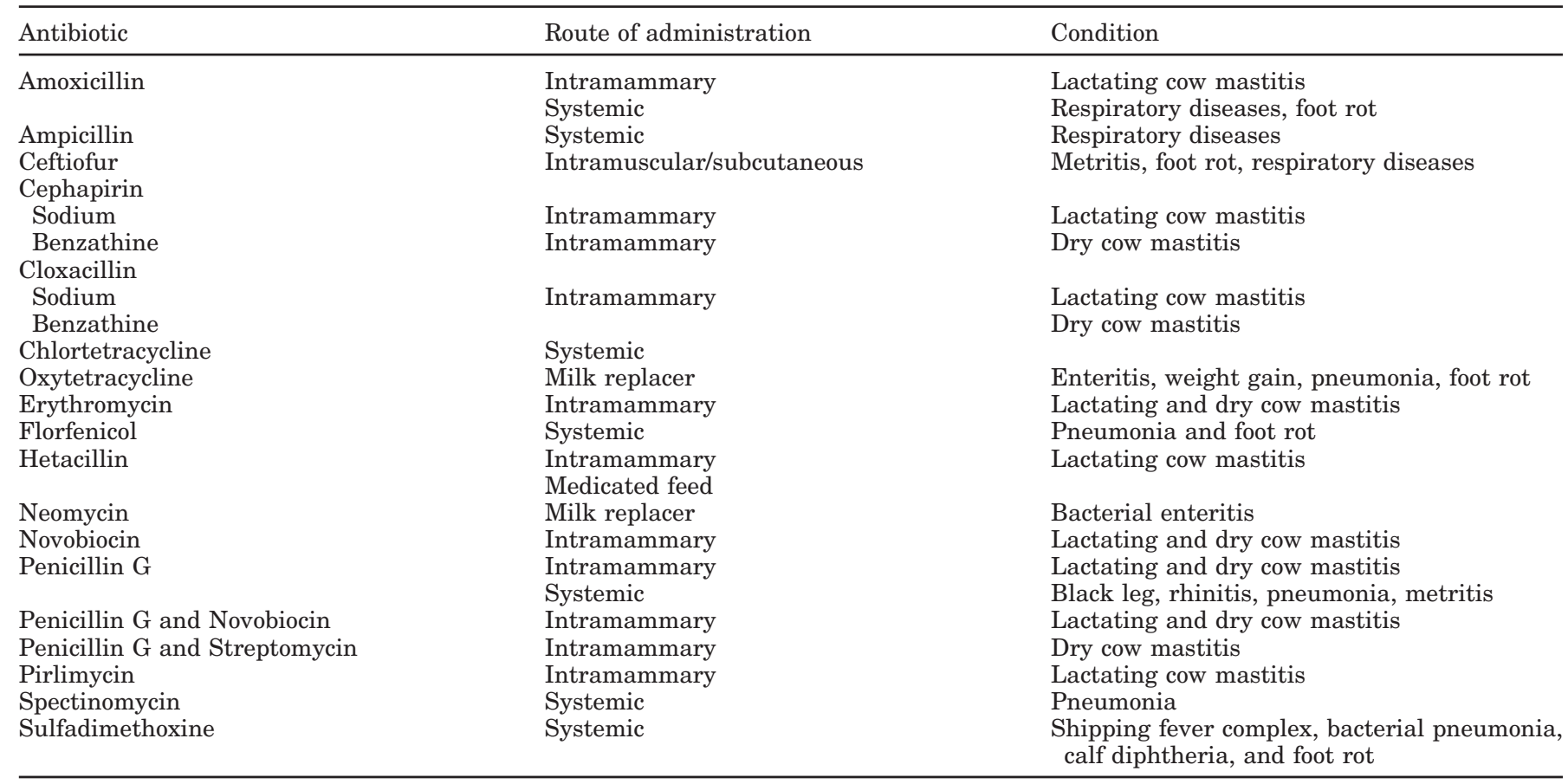

${ }^{1}$ Compiled from United States Pharmacopeia (http://www.usp.org/veterinary/monographs/main.html); Food and Drug AdministrationCenter for Veterinary Medicine (2004b) HFV-12, 301/594-1755, Infectious Mastitis Preparations (http://www.fda.gov/cvm/index/memos/ cvmm34.html); and the Code of Federal Regulations (CFR) (http://www.gpoaccess.gov/cfr/index.html).

Various practices that would help in avoiding residues in milk such as physically separating treated cows, marking them visibly, and milking them last in separate milking units were observed in $\geq 84 \%$ of farms (Table 1). Such practices are effective in preventing drug residues in milk (Talley, 1999). A significant number of dairy producers (58\%) routinely screened cows for antibiotics with an antibiotic residue detection test after freshening. Antibiotic residues in milk were detected in $3 \%$ of the dairy farms surveyed. Routine testing of treated cows for antibiotic residues is helpful in reducing the risk of residue occurrence in milk (McEwen et al., 1991).

Antibiotics that play a significant role in dairy cattle industry are listed in Table 2. Beta-lactam-based antibiotics such as penicillin, its derivatives, and cephalosporins are approved for use in dairy cattle. Beta-lactam-based formulations are available for treating foot rot, mastitis in lactating and dry cows, metritis, and respiratory diseases (United States Pharmacopeia). Tetracycline and neomycin combination is approved for prophylactic use in medicated milk replacers (Code of Federal Regulations, 2004). Because the withdrawal period for spectinomycin is not established in preruminating and lactating dairy cattle, this medication is not recommended for dairy cattle 20 mo of age or older (Food and Drug Administration-Center for Veterinary
Medicine, 2004a). Currently, sulfadimethoxine is the only sulfonamide labeled for treating lactating cattle with respiratory disease and foot rot. Extra-label use of sulfadimethoxine in lactating cattle is prohibited (Code of Federal Regulations, 2004).

The use of these antibiotics and the various clinical conditions for which they were used was determined from the records of 33 farms under study (Table 3). Enteritis and pneumonia were the predominant disease conditions observed in calves. Ortman and Svensson (2004) recorded disease and treatments of heifer calves $(\mathrm{n}=3081)$ from 112 Swedish dairy herds from birth to first calving. They reported that respiratory diseases and diarrhea were the most common disease conditions from birth to $210 \mathrm{~d}$. The number of farms that recorded clinical cases of pneumonia was the highest for calves (88\%) among animals of different age groups in our study. Twenty-five percent of calves with clinical pneumonia were treated (Table 3 ). The morbidity associated with calf pneumonia can vary as the disease can occur both endemically and as an outbreak (Ames, 1997). Waltner-Toews et al. (1986) reported that $15 \%$ of Ontario dairy calves were treated for pneumonia based on diagnosis by the dairy producers. Virtala et al. (1996) found that the crude risk for pneumonia was $11 \%$ when diagnosed by a caretaker and $25.6 \%$ when diagnosed by a veterinarian. 
Table 3. Prevalence of disease and health conditions in animals of different age groups.

\begin{tabular}{|c|c|c|c|c|}
\hline Dairy cattle & $\begin{array}{l}\text { Total number } \\
\text { of animals } \\
\text { ( } \mathrm{n}=33 \text { farms })\end{array}$ & $\begin{array}{l}\text { No. of farms (\%) } \\
\text { with recorded } \\
\text { clinical cases }\end{array}$ & $\begin{array}{l}\text { Range } \\
\text { of clinical } \\
\text { cases/farm/yr }\end{array}$ & $\begin{array}{l}\text { Clinical } \\
\text { cases }(\%) \\
\text { treated with } \\
\text { antibiotics }\end{array}$ \\
\hline \multicolumn{5}{|l|}{ Pneumonia } \\
\hline Calves & 390 & $29(88)$ & $0-14$ & $99(25)$ \\
\hline Heifers & 667 & $5(15)$ & $0-2$ & $7(1)$ \\
\hline Lactating cows & 2783 & $11(33)$ & $0-11$ & $71(3)$ \\
\hline Dry cow & 361 & $8(24)$ & $0-7$ & $37(10)$ \\
\hline \multicolumn{5}{|l|}{ Metritis } \\
\hline Heifers & 667 & $9(27)$ & $0-6$ & $26(4)$ \\
\hline Lactating cows & 2783 & $26(79)$ & $0-14$ & 294 \\
\hline Dry cows (early) & 361 & $7(21)$ & $0-9$ & $27(7)$ \\
\hline \multicolumn{5}{|l|}{ Foot rot } \\
\hline Calves & 390 & $3(9)$ & $0-3$ & $6(2)$ \\
\hline Heifers & 667 & $4(12)$ & $0-4$ & $10(1)$ \\
\hline Lactating cows & 2783 & $33(100)$ & $2-21$ & $459(16)$ \\
\hline Dry cows & 361 & $7(21)$ & $0-5$ & $17(5)$ \\
\hline \multicolumn{5}{|l|}{ Enteritis } \\
\hline Calves & 390 & $33(100)$ & $3-30$ & $141(36)$ \\
\hline Heifers & 667 & $6(18)$ & $0-7$ & $19(3)$ \\
\hline Lactating cows & 2783 & $9(27)$ & $0-15$ & $43(2)$ \\
\hline Dry cows & 361 & $4(12)$ & $0-4$ & $11(3)$ \\
\hline \multicolumn{5}{|l|}{ Clinical mastitis } \\
\hline Heifers & 667 & $10(30)$ & $0-6$ & $34(5)$ \\
\hline Lactating cows & 2783 & $33(100)$ & $3-30$ & 389 (14) \\
\hline $\begin{array}{l}\text { Dry cows } \\
\text { (early and late) }\end{array}$ & 361 & $9(27)$ & $0-7$ & $30(8)$ \\
\hline
\end{tabular}

With $36 \%$ of the calf population treated with antibiotics for enteritis, it was the single most commonly treated disease on the farms surveyed, as well as among various age groups. Calf loss from diarrhea is an important segment of total loss in the United States cattle industry. It was reported in the late 1970 s that enteric pathogens kill up to $25 \%$ of calves each year, resulting in more than $\$ 250$ million in losses (Hunt, 1985). When colibacillosis or salmonellosis is confirmed or is the suspected cause of diarrhea in calves, use of appropriate antimicrobial therapy plays an important role in restoring and maintaining health of calves (Roussel and Brumbaugh, 1991).

In lactating cattle, clinical mastitis was predominant and observed on all farms. Mastitis was previously reported to be the most common condition treated in lactating dairy cows (Mitchell et al., 1998). In the present study, antibiotics were used to treat clinical mastitis in $14 \%$ of lactating cows, $8 \%$ of cows in the early or late phases of their dry period, and 5\% of heifers (Table 3). The use of antibiotics continues to be a predominant practice for the treatment and control of mastitis ( $\mathrm{Ow}$ ens et al., 1997).

Other commonly observed disease conditions in lactating cattle were metritis and foot rot. Clinical cases of metritis in lactating cattle were recorded on $79 \%$ of farms; and $11 \%$ of the total lactating cattle were treated for metritis with antibiotics. Cows with dystocia, retained placenta, twins or stillbirths, and various meta- bolic disorders are more likely to develop metritis (Lewis, 1997). Use of systemic or intrauterine antimicrobial therapy is typical for treating metritis (Smith et al., 1998). Foot rot cases were detected on all of the 33 farms, with $16 \%$ of the lactating cattle treated with antibiotics (Table 3). Foot rot has been cited previously as a frequent health problem by dairy producers surveyed in Canada (Spicer et al., 1994). Foot rot is considered the most commonly occurring pathological condition in lactating dairy animals (Landais et al., 1989).

This study not only determined the diseases that were targeted for antibiotic intervention, but also the specific antimicrobial classes that were utilized. For example, cephapirin was a preferred drug for treating clinical mastitis in lactating cattle on $49 \%$ for the farms (Table 4). Other antibiotics used less frequently included penicillin $\mathrm{G}$ procaine (18\%), ceftiofur (18\%), pirlimycin, and amoxicillin. Previous studies showed that penicillin $\mathrm{G}$ procaine, pirlimycin, and amoxicillin could be used effectively to eliminate intramammary infections caused by environmental streptococci and Staphylococcus aureus (Owens et al., 1991; Jousimies-Somer et al., 1996; Gillespie et al., 2002). Therefore, the use of these antimicrobials to treat mastitis in lactating dairy cattle is appropriate. The use of ceftiofur to treat mastitis is an extra-label application and occasional use of this antimicrobial for this purpose was reported previously (Smith et al., 2004). Several recent studies explored the use of ceftiofur to treat mastitis with some 
Table 4. Documented disease or health conditions on dairy herds $(n=33)$ that required use of antibiotics.

\begin{tabular}{|c|c|c|c|c|c|c|c|c|c|c|c|}
\hline \multirow[b]{2}{*}{ Antimicrobial agent } & \multicolumn{9}{|c|}{ Therapeutic use } & \multicolumn{2}{|c|}{$\begin{array}{c}\text { Prophylactic } \\
\text { use }\end{array}$} \\
\hline & $\begin{array}{l}\text { Dry cow } \\
\text { treatment }\end{array}$ & Mastitis & Enteritis & Pneumonia & $\begin{array}{l}\text { Foot } \\
\text { rot }\end{array}$ & Metritis & Other & $\begin{array}{l}\text { Total } \\
\text { farms }\end{array}$ & $\%$ & $\begin{array}{l}\text { Total } \\
\text { farms }\end{array}$ & $\%$ \\
\hline Amoxicillin & & 4 & & 5 & 1 & & $1^{1}$ & $9^{2}$ & 27 & & \\
\hline Ampicillin & & & & $15^{3}$ & & & $2^{4}$ & $15^{2}$ & 46 & & \\
\hline Bacitracin-zinc & & & & & & & & & & $1^{5}$ & 3 \\
\hline Bambermycin & & & & & & & & & & 1 & 3 \\
\hline Carbadox & & & & & & & & & & $1^{5}$ & 3 \\
\hline Ceftiofur & & $6^{5}$ & & 16 & 3 & 5 & $1^{5}$ & $26^{1}$ & 79 & & \\
\hline Cephapirin benzathine & 17 & & & & & & & 17 & 52 & & \\
\hline Cephapirin sodium & & 16 & & & & & & 16 & 49 & & \\
\hline Chlortetracycline & & & 1 & 2 & & & & $3^{2}$ & 9.1 & 1 & 3 \\
\hline Cloxacillin benzathine & 5 & & & & & & & 5 & 15 & & \\
\hline Danofloxacin & & & & 1 & & & & 1 & 3 & & \\
\hline Erythromycin & & 3 & & & & & $1^{1}$ & $3^{2}$ & 9.1 & & \\
\hline Florfenicol & & & & 10 & & & & 10 & 30 & & \\
\hline Hetacillin & & 1 & & & & & & 1 & 3 & & \\
\hline Lincomycin & & & $1^{5}$ & & & & & 1 & 3 & & \\
\hline Neomycin & & & 2 & & & & & 2 & 6.1 & & \\
\hline Novobiocin & 9 & & & & & & & 9 & 27 & & \\
\hline Novobiocin and Penicillin G Procaine & 4 & & & & & & & 4 & 12 & & \\
\hline Oxytet-Neomycin & & & & & & & & & & 23 & 70 \\
\hline Penicillin G Procaine & 8 & 6 & & & & & $1^{6}$ & $15^{2}$ & 46 & & \\
\hline Pirlimycin & & 4 & & & & & & 4 & 12 & & \\
\hline Spectinomycin & & & $10^{5}$ & 14 & & & & $22^{2}$ & 67 & & \\
\hline Sulfadimethoxine & & & & 8 & 9 & & & $16^{2}$ & 49 & & \\
\hline Tetracycline & & & 1 & 2 & & & & $3^{2}$ & 9.1 & & \\
\hline Tilmicosin & & & & 1 & & & & 1 & 3 & & \\
\hline
\end{tabular}

${ }^{1}$ Pink eye.

${ }^{2}$ Farms used same antibiotic to treat different conditions.

${ }^{3}$ Used in calves.

${ }^{4}$ Navel ill.

${ }^{5}$ Extra-label use.

${ }^{6}$ Wounds. 
success (Oliver et al., 2004; Smith et al., 2004). The advantages of using this drug is that it is approved for use in lactating cattle and when administered systemically to label dose of up to $2.2 \mathrm{mg} / \mathrm{kg}$ daily for $5 \mathrm{~d}$, it does not have a withholding period for milk or meat (Erskine et al., 2002). For dry cow therapy on farms, preferred drugs were cephapirin (52\%), novobiocin (27\%), penicillin G procaine (24\%), and cloxacillin (15\%). These antibiotics are effective in protecting against new intramammary infections (Sol and Melenhorst, 1990; Sanchez and Watts, 1999). The data from this study confirm that dairy cattle are exposed to a variety of beta-lactam-based antibiotics.

Several antibiotic classes are currently labeled in the United States for the treatment of enteritis in calves, including amoxicillin, chlortetracycline, neomycin, oxytetracycline, streptomycin, sulfachloropyridazine, sulfamethazine, and tetracycline (Constable, 2004). Only chlortetracycline, tetracycline, and neomycin among the approved antibiotics were used on some farms. Extra-label use of spectinomycin was observed on $30 \%$ of dairy farms for treating enteritis because it is only approved for treating pneumonia in dairy cattle less than 20 mo of age (Table 2).

For treatment of respiratory diseases, 10 different antibiotics were used. The antibiotics that were preferred on most farms were ampicillin (45\%, only in calves), ceftiofur (48\%), florfenicol (30\%), and spectinomycin (42\%) (Table 4). Sulfadimethoxine also was used on $27 \%$ of the farms to treat animals with pneumonia. Other antibiotics used were amoxicillin, tetracycline, danofloxacin, and tilmicosin. Antibiotics like spectinomycin, sulfadimethoxine, and tetracycline commonly are used for the treatment of pneumonia in cattle (Prescott and Baggot, 1988; Burrows and Ewing, 1989). Danofloxacin has been approved for treatment of respiratory diseases in chickens, cattle, and pigs, but has not been indicated for use in dairy cattle. Tilmicosin, a macrolide, has been approved for treatment of bovine respiratory disease in the United States [Code of Federal Regulations (revised), 2004]. Ceftiofur was the drug of choice for treating respiratory diseases on most farms. Nearly all of the current literature pertains to the efficacy of ceftiofur for treating bovine respiratory diseases (Yancey et al., 1987; Hibbard et al., 2002; Hornish and Kotarski, 2002). Very few reports on the amount of actual ceftiofur usage are available in the literature. Zwald et al. (2004) reported that $80 \%$ of conventional dairy farms located in Michigan, Minnesota, New York, and Wisconsin used ceftiofur for treating respiratory diseases. Ampicillin (22\%) and florfenicol (7\%) were also used on these farms for the same diseases.

The most commonly used drug for foot rot therapy was sulfadimethoxine $(27.3 \%)$. Sulfonamides are not directly effective against most obligate anaerobes, but may affect aerobic organisms that create the microenvironment in which Fusobacterium thrive during a foot rot condition, according to the United States Pharmacopeia (http://www.usp.org, accessed Sept. 18, 2004). Ceftiofur was used for treatment of foot rot on 3 farms in the current study. Ceftiofur was valuable in treating acute foot rot condition following visual confirmation of the disease (Morck et al., 1998; Kausche and Robb, 2003). Ceftiofur also has been proven effective for the treatment of acute postpartum metritis in dairy cows (Chenault et al., 2004) and was the drug of choice for metritis treatment on 5 of the 33 farms.

The combination of oxytetracycline and neomycin was used widely on farms ( 23 of $33 ; 70 \%$ ) for prophylaxis in calves to prevent bacterial diarrhea (Tables 4). Some farms also used chlortetracycline, which has been approved for improving weight gain and feed efficiency. Use of medicated milk replacers was reported to reduce the severity of diarrhea and number of days of diarrhea in calves (Quigley et al., 1997). Chlortetracycline and oxytetracycline in combination with neomycin, decoquinate, and lasalocid are the only approved antimicrobial agents that can be used in medicated milk replacers (USDA/APHIS/VS/CEAH, 1998). According to the National Dairy Herd Evaluation Project, around $60 \%$ of US dairy producers use milk replacers for feeding neonatal calves. Medicated milk replacers were used by $59.6 \%$ of dairy producers for calves from birth to $3 \mathrm{wk}$ of age, whereas use increased to $70.7 \%$ for older calves from 3 wk to weaning age (Heinrichs et al., 1995). Extra-label prophylactic use of bacitracin-zinc and carbadox was also observed in some dairy herds. Bacitracin-zinc, a coccidiostat indicated for use in poultry (Code of Federal Regulations, 2004), was used in cattle. Carbadox is actually indicated for use in swine feed (FDA-CVM, 2004).

Based on the findings of our survey, it can be inferred that antibiotics, particularly tetracyclines and beta-lactams, are extensively used for prevention and treatment of disease in dairy animals in Pennsylvania. These antibiotics could exert selective antibiotic pressure and may result in emergence of antibiotic-resistant bacteria in dairy environments in Pennsylvania.

\section{CONCLUSIONS}

Absence of antibiotic treatment records, lack of written plans for treating sick animals, failure to consult a veterinarian for treating sick animals, and failure to complete antimicrobial treatment course are factors that can lead to inappropriate use of antibiotics. There was considerable variation in the management practices associated with antibiotic use on farms. The most important clinical conditions on farms for which antibi- 
otics were used extensively included mastitis and foot rot in lactating cattle, and enteritis and respiratory disease in calves.

Dry cow therapy with antibiotics was widely used on farms to aid in mastitis control. In calves, prophylactic use of oxytetracycline and neomycin combination was common to prevent enteritis. Among all the disease conditions, pneumonia was the only one where various classes of antibiotics were used. Use of third-generation cephalosporins such as ceftiofur was common on farms and was often used as extra-label on some farms. Studies addressing public health issues associated with antibiotic usage and emerging antibiotic resistance on dairy farms should take into consideration beta-lactams and tetracyclines as they were the most widely used antibiotics on dairy farms.

\section{REFERENCES}

Ames, T. R. 1997. Dairy calf pneumonia. The disease and its impact. Vet. Clin. North Am. Food Anim. Pract. 13:379-391.

Austin, B. 1985. Antibiotic pollution from fish farms: Effects on aquatic microflora. Microbiol. Sci. 2:113-117.

Baquero, F., M. C. Negri, M. I. Morosini, and J. Blazquez. 1998. Antibiotic-selective environments. Clin. Infect. Dis. 27(Suppl. 1):S5-S11.

Bates, J., J. Z. Jordens, and D. T. Griffiths. 1994. Farm animals as a putative reservoir for vancomycin-resistant enterococcal infection in man. J. Antimicrob. Chemother. 34:507-514.

Burrows, G. E., and P. Ewing. 1989. In vitro assessment of the efficacy of erythromycin in combination with oxytetracycline or spectinomycin against Pasteurella haemolytica. J. Vet. Diagn. Invest. 1:299-304.

Chee-Sanford, J. C., R. I. Aminov, I. J. Krapac, N. Garrigues-Jeanjean, and R. I. Mackie. 2001. Occurrence and diversity of tetracycline resistance genes in lagoons and groundwater underlying two swine production facilities. Appl. Environ. Microbiol. 67:1494-1502.

Chenault, J. R., J. F. McAllister, S. T. Chester, Jr., K. J. Dame, F. M. Kausche, and E. J. Robb. 2004. Efficacy of ceftiofur hydrochloride sterile suspension administered parenterally for the treatment of acute postpartum metritis in dairy cows. JAVMA 224:1634-1639.

Code of Federal Regulations. 2004. Title 21 Part 558. New animal drugs for use in animal feeds. http://www.gpoaccess.gov/cfr/index.html. Accessed Sept. 18, 2004.

Code of Federal Regulations (revised). 2004. Tilmicosin (21CFR 522.2471) and Danofloxacin (21CFR 522.522). http://www.gpoaccess.gov/cfr/index.html. Accessed Jan. 12, 2005.

Constable, P. D. 2004. Antimicrobial use in the treatment of calf diarrhea. J. Vet. Intern. Med. 18:8-17.

Corpet, D. E. 1996. Microbiological hazards for humans of microbial growth promoter use in animal production. Rev. Med. Vet. 147:851-862.

Council for Agricultural Science and Technology. 1981. Antibiotics in Animal Feeds. Report No. 88. Council for Agricultural Sciences and Technology, Ames, Iowa.

Crawford, L. M., and R. H. Teske. 1983. Growth promotants approved in the U.S. Vet. Res. Commun. 7:83-84.

Droumev, D. 1983. Review of antimicrobial growth promoting agents available. Vet. Res. Commun. 7:85-89.

Erskine, R. J., P. C. Bartlett, J. L. VanLente, and C. R. Phipps. 2002. Efficacy of systemic ceftiofur as a therapy for severe clinical mastitis in dairy cattle. J. Dairy Sci. 85:2571-2575.

Food and Drug Administration-Center of Veterinary Medicine (FDACVM). 2004a. FDA-approved animal drug products online data- base system. Online. http://dil.vetmed.vt.edu/NadaFIrst/NADA.cfm. Accessed Sept. 18, 2004.

Food and Drug Administration-Center for Veterinary Medicine (FDA-CVM). 2004b. HFV-12, 301/594-1755, Infectious Mastitis Preparations. $\quad$ http://www.fda.gov/cvm/index/memos/ cvmm34.html. Accessed Sept. 18, 2004.

Frost, A. J. 1991. Antibiotics and animal production. Pages 181-194 in World Animal Science Microbiology of Animals and Animal Products. J. B. Woolcock, ed. Elsevier, New York, NY.

Gillespie, B. E., H. Moorehead, P. Lunn, H. H. Dowlen, D. L. Johnson, K. C. Lamar, M. J. Lewis, S. J. Ivey, J. W. Hallberg, S. T. Chester, and S. P. Oliver. 2002. Efficacy of extended pirlimycin hydrochloride therapy for treatment of environmental Streptococcus spp. and Staphylococcus aureus intramammary infections in lactating dairy cows. Vet. Ther. 3:373-380.

Grave, K., C. Greko, L. Nilsson, K. Odensvik, T. Mork, and M. Ronning. 1999. The usage of veterinary antibacterial drugs for mastitis in cattle in Norway and Sweden during 1990-1997. Prev. Vet. Med. 42:45-55.

Hays, V. W. 1986. Benefits and risks of antibiotics use in agriculture. Pages 74-78 in Agricultural uses of antibiotics. Series 320, American Chemical Society Symposium, W. A. Moats, ed. American Chemical Society, Washington, DC

Heinrichs, A. J., S. J. Wells, and W. C. Losinger. 1995. A study of the use of milk replacers for dairy calves in the United States. J. Dairy Sci. 78:2831-2837.

Hibbard, B., E. J. Robb, S. T. Chester, Jr., K. J. Dame, W. W. Moseley, and W. L. Bryson. 2002. Dose determination and confirmation for ceftiofur crystalline-free acid administered in the posterior aspect of the ear for control and treatment of bovine respiratory disease. Vet. Ther. 3:22-30.

Hornish, R. E., and S. F. Kotarski. 2002. Cephalosporins in veterinary medicine-Ceftiofur use in food animals. Curr. Top. Med. Chem. 2:717-731.

Hunt, E. 1985. Symposium on Calf Diarrhea. Vet. Clin. North Am. Food Anim. Pract. 1: 443.

Institute of Medicine (IOM). 1989. Human health risks with subtherapeutic use of penicillin or tetracyclines in animal feed. Committee on human health risk assessment on using subtherapeutic antibiotics in animal feeds. National Academy Press, Washington, DC.

Jayarao, B. M., N. V. Hedge, S. R. Pillai, D. R. Wolfgang, C. M. Burns, A. A. Sawant, and L. R. Hutchinson. 2002. Raw milk: Think before you drink. National Mastitis Council, Regional Meeting Proceedings. Syracuse, NY. Natl. Mastitis Counc., Madison, WI. Jousimies-Somer, H., S. Pyorala, and A. Kanervo. 1996. Susceptibilities of bovine summer mastitis bacteria to antimicrobial agents. Antimicrob. Agents Chemother. 40:157-160.

Kaneene, J. B., and A. S. Ahl. 1987. Drug residues in dairy cattle industry: Epidemiological evaluation of factors influencing their occurrence. J. Dairy Sci. 70:2176-2180.

Kausche, F. M., and E. J. Robb. 2003. A comprehensive review of ceftiofur sodium and hydrochloride formulations for treatment of acute bovine foot rot. Vet. Ther. 4:83-93.

Kelly, L., D. L. Smith, E. L. Snary, J. A. Johnson, A. D. Harris, M. Wooldridge, and J. G. Morris, Jr. 2004. Animal growth promoters: To ban or not to ban? A risk assessment approach. Int. J. Antimicrob. Agents 24:205-212.

Landais, E., J. B. Coulon, J. P. Garel, and A. Hoden. 1989. Characterization of the pathology of lactating cows based on the level of lactation. Principal factors in the variation and typing of pathologic profiles of lactation. Ann. Rech. Vet. 20:277-294.

Levy, S. B. 1992. The Antibiotic Paradox. How miracle drugs are destroying the miracle. Plenum Publishing, New York, NY.

Levy, S. B., J. P. Burke, and C. K. Wallace. 1987. Antibiotic use and antibiotic resistance worldwide. Rev. Infect. Dis. (Suppl. 3):9.

Lewis, G. S. 1997. Uterine health and disorders. J. Dairy Sci. 80:984-994.

McEwen, S. A., A. H. Meek, and W. D. Black. 1991. A dairy farm survey of antibiotic treatment practices, residue control methods and associations with inhibitors in milk. J. Food Prot. 54:454-459.

Mitchell, J. M., M. W. Griffiths, S. A. McEwen, W. B. McNab, and A. J. Yee. 1998. Antimicrobial drug residues in milk and meat: 
Causes, concerns, prevalence, regulations, tests, and test performance. J. Food Prot. 61:742-756.

Morck, D. W., M. E. Olson, T. J. Louie, A. Koppe, and B. Quinn. 1998. Comparison of ceftiofur sodium and oxytetracycline for treatment of acute interdigital phlegmon (foot rot) in feedlot cattle. JAVMA 212:254-257.

Oliver, S. P., B. E. Gillespie, S. J. Headrick, H. Moorehead, P. Lunn, H. H. Dowlen, D. L. Johnson, K. C. Lamar, S. T. Chester, and W. M. Moseley. 2004. Efficacy of extended ceftiofur intramammary therapy for treatment of subclinical mastitis in lactating dairy cows. J. Dairy Sci. 87:2393-2400.

Ortman, K., and C. Svensson. 2004. Use of antimicrobial drugs in Swedish dairy calves and replacement heifers. Vet. Rec. 154:136-140.

Owens, W. E., S. C. Nickerson, P. J. Washburn, and C. H. Ray. 1991. Efficacy of a cephapirin dry cow product for treatment of experimentally induced Staphylococcus aureus mastitis in heifers. J. Dairy Sci. 74:3376-3382.

Owens, W. E., C. H. Ray, J. L. Watts, and R. J. Yancey. 1997. Comparison of success of antibiotic therapy during lactation and results of antimicrobial susceptibility tests for bovine mastitis. J. Dairy Sci. 80:313-317.

Prescott, J. F., and J. D. Baggot. 1988. Antimicrobial therapy in veterinary medicine. Blackwell Scientific Publications, Boston, MA.

Quigley, J. D., III, J. J. Drewry, L. M. Murray, and S. J. Ivey. 1997. Body weight gain, feed efficiency, and fecal scores of dairy calves in response to galactosyl-lactose or antibiotics in milk replacers. J. Dairy Sci. 80:1751-1754.

Roussel, A. J., Jr., and G. W. Brumbaugh. 1991. Treatment of diarrhea of neonatal calves. Vet. Clin. North Am. Food Anim. Pract. 7:713-728.

Sanchez, M. S., and J. L. Watts. 1999. Enhancement of the activity of novobiocin against Escherichia coli by lactoferrin. J. Dairy Sci. 82:494-499.

Shitandi, A., and A. Sternesjo. 2004. Factors contributing to the occurrence of antimicrobial drug residues in Kenyan milk. J. Food Prot. 67:399-402.

Smith, B. I., G. A. Donovan, C. Risco, R. Littell, C. Young, L. H. Stanker, and J. Elliott. 1998. Comparison of various antibiotic treatments for cows diagnosed with toxic puerperal metritis. J. Dairy Sci. 81:1555-1562.

Smith, G. W., R. Gehring, J. E. Riviere, J. L. Yeatts, and R. E. Baynes. 2004. Elimination kinetics of ceftiofur hydrochloride after intramammary administration in lactating dairy cows. JAVMA 224:1827-1830.

Sol, J., and A. Melenhorst. 1990. Efficacy of a modified formula dry cow preparation for dairy cattle containing $600 \mathrm{mg}$ cloxacillin. Tijdschr. Diergeneeskd. 115:670-673.

Spicer, H. M., L. A. Goonewardene, A. O. McNeil, and W. L. Slack. 1994. Alberta dairy farm survey response. J. Dairy Sci. 77:3460-3472.

Talley, M. R. 1999. The national milk safety program and drug residues in milk. Vet. Clin. North Am. Food Anim. Pract. 15:63-73.

Tenover, F. C., and J. E. McGowan. 1996. Reasons for the emergence of antibiotic resistance. Am. J. Med. Sci. 311:9-16.

USDA/APHIS/VS/CEAH. 1998. A guide to modern calf milk replacer. Online. http://www.aphis.usda.gov/vs/ceah/ncahs/index.htm. Accessed Sept. 20, 2004.

U.S. International Trade Commission. 1987. Synthetic Organic Chemicals: United States Production and Sales, 1950-1986. U.S. Government Printing Office, Washington, DC.

United States Pharmacopeia. Online. http://www.usp.org/veterinary/ monographs/main.html. Accessed Sept. 18, 2004.

Virtala, A. M., G. D. Mechor, Y. T. Grohn, H. N. Erb, and E. J. Dubovi. 1996. Epidemiologic and pathologic characteristics of respiratory tract disease in dairy heifers during the first three months of life. JAVMA 208:2035-2042.

Waltner-Toews, D., S. W. Martin, A. H. Meek, and I. McMillan. 1986. Dairy calf management morbidity and mortality in Ontario Holstein herds. I: The data. Prev. Vet. Med. 4:103-124.

Yancey, R. J., Jr., M. L. Kinney, B. J. Roberts, K. R. Goodenough, J. C. Hamel, and C. W. Ford. 1987. Ceftiofur sodium, a broadspectrum cephalosporin: Evaluation in vitro and in vivo in mice. Am. J. Vet. Res. 48:1050-1053.

Zwald, A. G., P. L. Ruegg, J. B. Kaneene, L. D. Warnick, S. J. Wells, C. Fossler, and L. W. Halbert. 2004. Management practices and reported antimicrobial usage on conventional and organic dairy farms. J. Dairy Sci. 87:191-201. 